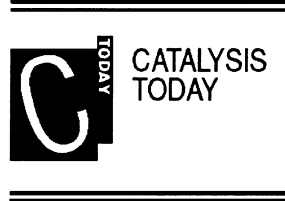

ELSEVIER

Catalysis Today 53 (1999) 433-441

www.elsevier.com/locate/cattod

\title{
New insights into methanol synthesis catalysts from X-ray absorption spectroscopy
}

\author{
George Meitzner ${ }^{\mathrm{a}, *}$, Enrique Iglesia ${ }^{\mathrm{b}}$ \\ ${ }^{a}$ Edge Analytical Inc., 2126 Allen Blvd \#3, Middleton WI 53562, USA \\ ${ }^{\mathrm{b}}$ Department of Chemical Engineering, University of California at Berkeley, Berkeley, CA 94720, USA
}

\begin{abstract}
X-ray absorption spectroscopic studies from several different groups provide a consistent structural picture of methanol synthesis catalysts. Copper metal is the principal $\mathrm{Cu}$ species detected in all in-situ XAS studies. A small amount of $\mathrm{Cu}$ (II) persisted in many samples reduced below $600 \mathrm{~K}$, but it appears to be catalytically irrelevant. $\mathrm{Cu}(\mathrm{I})$ was not detected in any of the in-situ XAS studies. The $\mathrm{Zn}$ structure did not change in response to chemical treatments in any of the ZnO-containing methanol synthesis catalysts.

We conclude that the slow approach to steady-state rate of methanol synthesis from $\mathrm{CO} / \mathrm{H}_{2}$ mixtures cannot result from changes in the $\mathrm{Cu}$ metal component of $\mathrm{Cu} / \mathrm{SiO}_{2}$ catalysts. By eliminating this possibility, we provide indirect evidence for the proposal that initial induction periods reflect slow changes in the surface of the $\mathrm{SiO}_{2}$ or $\mathrm{ZnO}$ component in the catalysts. A bifunctional mechanism involving the formation of formate from $\mathrm{CO}$ on support hydroxyl groups would increase methanol synthesis rates as $\mathrm{OH}$ groups are formed by hydrolysis of $\mathrm{Si}-\mathrm{O}$ bonds using the $\mathrm{H}_{2} \mathrm{O}$ formed in slow methanation side reactions. The bifunctional mechanism is not required for the synthesis of methanol from $\mathrm{CO}_{2}$-containing mixtures, because formate can form on $\mathrm{Cu}$ directly from $\mathrm{CO}_{2}$ and $\mathrm{H}_{2}$. (C1999 Elsevier Science B.V. All rights reserved.
\end{abstract}

Keywords: X-ray absorption spectroscopy; Methanol synthesis; Catalyst; Copper metal

\section{Introduction}

Catalytic methanol synthesis is vastly superior to the process it replaced, the destructive distillation of wood. Early catalysts consisted of $\mathrm{ZnO}$ and $\mathrm{Cr}_{2} \mathrm{O}_{3}$ mixtures and produced methanol in low yields from CO- $\mathrm{H}_{2}$ mixtures at high temperatures $(593-673 \mathrm{~K})$ and pressures (250-350 bar). Chromia was included in $\mathrm{ZnO}$ catalysts as a structural promoter, in preference over alumina, which catalyzes methanol dehydration to dimethyl ether. More active $\mathrm{Cu}$-based catalysts were introduced commercially well after their discov-

\footnotetext{
${ }^{*}$ Corresponding author.
}

ery, because their poisoning by feed sulfur could not prevented using available purification methods [1].

Current methanol synthesis catalysts are prepared by co-precipitation of $\mathrm{Cu}, \mathrm{Zn}$, and $\mathrm{Al}$ as hydroxides or carbonates, which are then decomposed to mixed oxides by treatment in air and reduced in $\mathrm{H}_{2}$ before use. Methanol synthesis feeds contain $\mathrm{CO}, \mathrm{H}_{2}$, and $\mathrm{CO}_{2}$; the latter is introduced intentionally because it increases the rate of $\mathrm{CO}$ hydrogenation reactions. The historical evolution of methanol synthesis catalysts and processes has led to two natural issues for investigation. One is the role of $\mathrm{Cu}$ and its chemical state during reaction. In examining the role of $\mathrm{Cu}$, it seems surprising that the active component in early methanol synthesis catalysts $(\mathrm{ZnO})$ should be- 


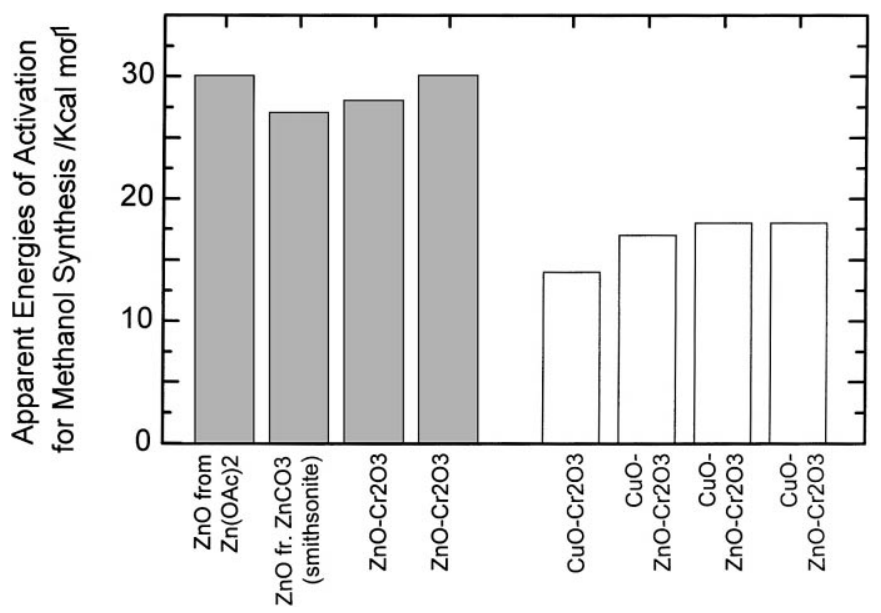

Fig. 1. Apparent energies of activation measured over methanol synthesis catalysts containing only $\mathrm{Zn}$ and a $\mathrm{Cr}_{2} \mathrm{O}_{3}$ structural promoter, or including $\mathrm{Cu}$ [1]. Shaded bars at left refer to different preparations in which $\mathrm{ZnO}$ is the only active component. Bars at right refer to different preparations of catalysts that contain $\mathrm{Cu}$ or $\mathrm{Cu}$ and $\mathrm{ZnO}$.

come the best promoter for $\mathrm{Cu}$ in the current catalysts. The other is the mechanism of $\mathrm{CO}$ and $\mathrm{CO}_{2}$ hydrogenation to form methanol. Some studies conclude that methanol is formed via identical pathways on $\mathrm{Cu} / \mathrm{ZnO} / \mathrm{Al}_{2} \mathrm{O}_{3}$ and on $\mathrm{ZnO} / \mathrm{Cr}_{2} \mathrm{O}_{3}$. In this proposal, $\mathrm{Cu}$ acts as an intracrystalline promoter for $\mathrm{ZnO}$, and the role of $\mathrm{CO}_{2}$ is to prevent the reduction of $\mathrm{Cu}$ cations to $\mathrm{Cu}$ metal during reaction [2-5]. Other studies conclude that the mechanism of methanol synthesis is different on $\mathrm{Cu} / \mathrm{ZnO}$ and $\mathrm{ZnO} / \mathrm{Cr}_{2} \mathrm{O}_{3}$, and that $\mathrm{Cu}$ is involved directly in the synthesis of methanol. Indeed, methanol synthesis activation energies are much lower on $\mathrm{Cu}$-containing catalysts than on $\mathrm{ZnO} / \mathrm{Cr}_{2} \mathrm{O}_{3}$ (Fig. 1), suggesting different pathways. These differences in activation energy, however, are not sufficient to distinguish promotion of $\mathrm{ZnO} / \mathrm{Cr}_{2} \mathrm{O}_{3}$ from a mechanistic shift.

Recent studies agree that $\mathrm{CO}_{2}$ rather than $\mathrm{CO}$ is the direct precursor to $\mathrm{CH}_{3} \mathrm{OH}$ on $\mathrm{Cu}$-containing catalysts, based on the initial appearance of ${ }^{13} \mathrm{CH}_{3} \mathrm{OH}$ from $\mathrm{CO} /{ }^{13} \mathrm{CO}_{2} / \mathrm{H}_{2}$ mixtures [6], on infrared spectra of adsorbed intermediates $[7,8]$, and on transient kinetic studies [9]. It has even been reported that methanol synthesis from mixtures of $\mathrm{H}_{2}$ and $\mathrm{CO}$ does not occur on $\mathrm{Cu} / \mathrm{SiO}_{2}$ [10]. Methanol synthesis rates reach a maximum at intermediate $\mathrm{CO}_{2}$ concentrations, above which its promoting effect is offset by the oxidation of the active $\mathrm{Cu}$ metal sites into inactive species [2]. Thus, the oxidation state of $\mathrm{Cu}$ depends not only on catalyst composition and pre-treatment conditions, but also on the feed and product compositions during steady-state catalysis.

The oxidation state of $\mathrm{Cu}$ during methanol synthesis is difficult to establish. Various studies have shown that $\mathrm{Cu}$ single-crystal or polycrystalline foil surfaces catalyze methanol synthesis from $\mathrm{CO}_{2} / \mathrm{H}_{2}$ mixtures $[11,12]$. X-ray diffraction studies provide an incomplete picture, because $\mathrm{Cu}$-containing phases become detectable only when present as catalytically irrelevant large crystallites and only infrequently on well-prepared active catalysts, whether or not reaction conditions were maintained $[13,14]$. X-ray photoelectron spectroscopy (XPS) studies have detected significant $\mathrm{Cu}(\mathrm{I})$ and $\mathrm{Cu}(\mathrm{II})$ concentrations in materials prepared in a treatment cell and then transferred into a vacuum chamber for surface analysis [4]. This approach cannot detect $\mathrm{Cu}$ species present during catalysis, because they are likely to be modified by the quenching protocol, by oxidation with air during transfer into the vacuum system, or by autoxidation using protons formed during the initial reduction of the $\mathrm{Cu}$ oxide catalyst precursors.

X-ray absorption spectroscopy (XAS) is well suited for in-situ studies of the $\mathrm{Cu}$ oxidation state and structure during methanol synthesis, and several groups have applied it. XAS provides element-specific information, so that the $\mathrm{Cu}$ and $\mathrm{Zn}$ species can be studied independently, even though all mixed phases may exist. 
The study that first reported the use of Fourier transforms to obtain radial distribution function around the absorber from the XAS fine structure (i.e. extended X-ray absorption fine-structure spectrum, EXAFS) used a $\mathrm{Cu}$ catalyst and stated the significance of the study to methanol synthesis catalysis [15].

Several reports describe X-ray absorption studies of $\mathrm{Cu}$-based catalysts prepared in reactors and then transferred into the X-ray absorption cells using protocols designed to minimize exposure to air. Vlaic et al. $[16,17]$ investigated $\mathrm{Cu}-\mathrm{ZnO} / \mathrm{Al}_{2} \mathrm{O}_{3}$ catalysts reduced at $503 \mathrm{~K}$. After reduction, the catalysts were pressed into wafers and X-ray spectra taken in a $\mathrm{He}$ atmosphere. Analysis of the X-ray absorption spectra near the edge showed that some catalysts contained only $\mathrm{Cu}(0)$, while others contained residual $\mathrm{CuO}$, although the reason for the difference was not discussed. No $\mathrm{Cu}(\mathrm{I})$ was detected in reduced samples. A separate study reported XPS and XAS data on $\mathrm{Cu} / \mathrm{ZnO}$ catalysts prepared ex-situ and transferred into an absorption cell or a vacuum chamber [4]. Catalysts were activated at $493 \mathrm{~K}$ for $4-8 \mathrm{~h}$ in a $\mathrm{CO}_{2} / \mathrm{CO} / \mathrm{H}_{2} / \mathrm{N}_{2}$ (4/0.5/2.25/93.25\%) mixture saturated with $\mathrm{H}_{2} \mathrm{O}$ (temperature not specified). $\mathrm{Cu} \mathrm{K}$-edge XAS at room temperature detected $\mathrm{Cu}(0), \mathrm{Cu}(\mathrm{I})$, and $\mathrm{Cu}(\mathrm{II})$, but the relevance of these findings to the state of $\mathrm{Cu}$ during steady-state catalysis or even after initial pretreatment is questionable because the mild ex-situ treatment is unlikely to reduce $\mathrm{Cu}$ atoms that would reduce during more realistic pre-treatments or even during reactions of $\mathrm{CO} / \mathrm{H}_{2} / \mathrm{CO}_{2}$ mixtures. Sankar et al. $[18,19]$ reduced $\mathrm{Cu} / \mathrm{ZnO}$ catalysts containing 10,20 , and $33 \mathrm{wt} . \% \mathrm{Cu}$ at $523 \mathrm{~K}$ in $\mathrm{H}_{2}$ for $5 \mathrm{~h}$, then transferred them into a spectroscopic cell. They detected $\mathrm{Cu}(0)$ and substantial amounts of $\mathrm{Cu}(\mathrm{I})$ and $\mathrm{Cu}(\mathrm{II})$. The relative amounts were not reported, but the average number of oxygen neighbors around a $\mathrm{Cu}$ atom was highest in the catalyst with the lowest $\mathrm{Cu}$ loading, most likely indicating the highest fraction of oxidized $\mathrm{Cu}$ in that sample. Another in-situ study by this group also detected $\mathrm{Cu}$ in all three oxidation states [20], but sample wafers contained a binder that may not be completely removed during reduction and may have protected some $\mathrm{CuO}$ from contact with $\mathrm{H}_{2}$.

Several recent reports demonstrate how XAS studies at reaction conditions are essential to determine the oxidation state and structure of $\mathrm{Cu}$ species during methanol synthesis [21-23]. $\mathrm{Cu}$ crystallites in $\mathrm{Cu}-\mathrm{Zn}$ binary catalysts were completely reduced to $\mathrm{Cu}(0)$ after treatment with $\mathrm{H}_{2}$ at $493 \mathrm{~K}$, but remained as $\mathrm{Cu}$ (II) in $\mathrm{Cu}-\mathrm{Zn}-\mathrm{Al}$ ternary catalysts after $\mathrm{H}_{2}$ treatment at $493 \mathrm{~K}$ [21]. $\mathrm{Cu}(\mathrm{II})$ in a ternary with $5 \mathrm{wt} \% \mathrm{Cu}$ reduced completely to $\mathrm{Cu}(0)$ at $533 \mathrm{~K}$ and formed $\mathrm{Cu}$ clusters too small to produce X-ray diffraction lines. Larger $\mathrm{Cu}$ crystallites presenting a radial distribution function characteristic of bulk $\mathrm{Cu}$ formed on ternary catalyst with higher $\mathrm{Cu}$ content $(27 \mathrm{wt} \% \mathrm{Cu})$ after similar treatments $[21,22]$. $\mathrm{Cu}(\mathrm{I})$ or $\mathrm{Cu}(\mathrm{II})$ species were not detected in any of the catalysts after reduction at $533 \mathrm{~K}$ by these first true in-situ studies of methanol synthesis catalysts.

Several groups have reported the results of combined XRD/XAS in-situ studies of methanol synthesis catalysts. Couves et al. [23] prepared a material resembling a methanol synthesis catalyst by treating the mineral aurichalchite $\left(\mathrm{Cu}_{5-\mathrm{x}} \mathrm{Zn}_{\mathrm{x}}(\mathrm{OH})_{6}\left(\mathrm{CO}_{3}\right)_{2}\right)$ in air at $723 \mathrm{~K}$ and then reducing in $\mathrm{H}_{2}$ at $543 \mathrm{~K}$ and then $773 \mathrm{~K}$. XAS spectra and XRD patterns were measured simultaneously. $\mathrm{Cu}(0)$ crystallites of about $10 \mathrm{~nm}$ diameter were detected after reduction at $543 \mathrm{~K}$. As the reduction temperature was increased to $773 \mathrm{~K}$, the $\mathrm{Cu}(0)$ XRD lines narrowed, and the amplitude of the EXAFS signal declined. This decrease in the EXAFS signal and in the corresponding intensity of the radial distribution function typically reflects a decrease in the average coordination number of $\mathrm{Cu}$ atoms (higher dispersion, smaller crystallites) or greater structural disorder. The apparently contradictory results from XRD and EXAFS measurements were attributed to incorporation of $\mathrm{Zn}$ atoms into the $\mathrm{Cu}$ lattice resulting in greater structural disorder. However, this interpretation may be faulted insofar as structural disorder also broadens X-ray diffraction lines.

An alternative interpretation was suggested in a combined XAS/XRD in-situ study, using a thin quartz capillary as a cell with hydrodynamics resembling those in well-designed tubular plug-flow reactor [24]. A comparison was made between $5 \% \mathrm{Cu} / \mathrm{SiO}_{2}$ and $5 \% \mathrm{Cu} / \mathrm{ZnO}$ catalysts, reduced in $\mathrm{CO} / \mathrm{CO}_{2} / \mathrm{H}_{2} / \mathrm{Ar}(0.5 / 4 / 4 / 91.5)$ mixtures at $493 \mathrm{~K}$ and then used in methanol synthesis with either $\mathrm{CO}_{2} / \mathrm{H}_{2}$ (10/90), $\mathrm{CO} / \mathrm{CO}_{2} / \mathrm{H}_{2}(5 / 5 / 90)$ or $\mathrm{H}_{2} \mathrm{O} / \mathrm{CO} / \mathrm{CO}_{2} / \mathrm{H}_{2}$ (3/4.85/4.85/87.3) mixtures, all at atmospheric pressure [24,25]. In both catalysts and with all synthesis gas compositions, $\mathrm{Cu}(0)$ was the most abundant species at $493 \mathrm{~K}$. The structures and coordination 
numbers of $\mathrm{Cu}$ species on the $\mathrm{SiO}_{2}$ support were not sensitive to the composition of the gas phase. In contrast, the $\mathrm{Cu}-\mathrm{Cu}$ coordination number for $\mathrm{Cu}$ metal particles on $\mathrm{ZnO}$ changed reversibly as feed composition was varied. $\mathrm{Cu}$ particles increased in dispersion (i.e. became smaller) when water was removed from the synthesis gas stream. These data led to a model that correlated the relative interfacial area between $\mathrm{Cu}$ metal and $\mathrm{ZnO}$ in $\mathrm{Cu}-\mathrm{ZnO}$ with the reduction potential of the gas mixture, which determined the extent of reduction of the $\mathrm{ZnO}$ component and the consequent spreading of $\mathrm{Cu}$ metal species on $\mathrm{ZnO}$ [26]. A rate law was developed that incorporated $\mathrm{H}_{2} \mathrm{O}$ partial pressure only in a term that predicted its effect on $\mathrm{Cu}$ surface area. This successfully predicted rates measured under conditions differing only in $\mathrm{H}_{2} \mathrm{O}$ concentration. The authors conclude that reconstruction of $\mathrm{Cu}$ particles in the presence of $\mathrm{H}_{2} \mathrm{O}$ provide a more reasonable explanation than competitive adsorption for the observed inhibition of methanol synthesis reaction rates by $\mathrm{H}_{2} \mathrm{O}$ [27]. In reference [23], a simultaneous sharpening of XRD lines for $\mathrm{Cu}$ metal, and a decrease in $\mathrm{Cu}$ EXAFS amplitude, was observed as the reduction temperature was increased from 543 to $773 \mathrm{~K}$. Since XRD is most sensitive to the largest particles, but EXAFS also detects the smallest, it appears that Couves et al. [23] detected the evolution of a bimodal distribution of crystallite sizes, with the largest $\mathrm{Cu}$ particles getting larger and the smallest getting smaller. XAS alone cannot detect a bimodal particle size distribution, but disagreement between XAS and XRD on average crystallite size provides circumstantial evidence for bimodal distributions.

All available in-situ XAS data support the role of $\mathrm{Cu}(0)$ as the active species and as the most abundant $\mathrm{Cu}$ species in working methanol synthesis catalysts using $\mathrm{CO}_{2} / \mathrm{CO} / \mathrm{H}_{2}$ feeds. The small $\mathrm{Cu}$ particles required for high volumetric productivity form in a narrow range of pre-treatment temperatures. Crystallite growth is rapid in $\mathrm{H}_{2}$ well below $700 \mathrm{~K}$, but complete reduction requires temperatures above $500 \mathrm{~K}$. Brands, et al. [28] recently reported that $\mathrm{Cu}$ in $14 \% \mathrm{Cu} / 7 \%$ $\mathrm{Zn} / \mathrm{SiO}_{2}$ became reduced in $\mathrm{H}_{2}$ at $693 \mathrm{~K}$ but spontaneously re-oxidized when $\mathrm{He}$ or vacuum replaced the $\mathrm{H}_{2}$ atmosphere. Tohji et al. [29] reported similar behavior for $\mathrm{Cu}$ in a $\mathrm{Cu} / \mathrm{ZnO}$ catalyst reduced in $\mathrm{H}_{2}$ between 400 and $550 \mathrm{~K}$, with re-oxidation observed below $400 \mathrm{~K}$ in non-reducing environments. The authors attributed these results to spontaneous autoxidation by protons left behind during the initial reduction. Highly dispersed $\mathrm{Cu}$ would efficiently scavenge oxygen from $\mathrm{O}_{2}$ or $\mathrm{H}_{2} \mathrm{O}$ in the absence of a reducing atmosphere. However, these workers appear to have used the appropriate measures to remove oxygen from the inlet gas. The argument for autoxidation would have been strengthened if an indicating oxygen trap had also been placed at the outlet of the in-situ cell, to confirm that the cell itself was not leaking.

In this paper, we report a structural study of a catalyst comprising $2.1 \mathrm{wt} . \% \mathrm{Cu} / \mathrm{SiO}_{2}$. This same catalyst was used in a previous study to establish the role of metallic $\mathrm{Cu}$ in methanol synthesis [6]. Silica supports have not been as extensively studied as $\mathrm{ZnO}$, $\mathrm{Al}_{2} \mathrm{O}_{3}$, or $\mathrm{ZrO}_{2}$ in methanol synthesis catalysts. However, $\mathrm{SiO}_{2}$ provides a good model system because it is widely regarded as unreducible under synthesis conditions. Although $\mathrm{Cu} / \mathrm{SiO}_{2}$ is not used commercially for synthesis of methanol, the observed rate of $\mathrm{CO} / \mathrm{CO}_{2}$ hydrogenation to $\mathrm{CH}_{3} \mathrm{OH}$ with this catalyst, expressed per $\mathrm{Cu}$-site, was within a factor of three of the rates reported by others over $\mathrm{Cu} / \mathrm{ZnO}$ and $\mathrm{Cu} / \mathrm{ZnO} / \mathrm{Al}_{2} \mathrm{O}_{3}$ catalysts under comparable conditions [6].

\section{Experimental}

A $\mathrm{Cu} / \mathrm{SiO}_{2}$ catalyst $(2.1 \mathrm{wt} . \% \mathrm{Cu})$ was prepared by urea-assisted decomposition of aqueous copper nitrate onto Davison 62 silica, as described in reference [6]. The $\mathrm{Cu}$ dispersion measured by $\mathrm{N}_{2} \mathrm{O}$ frontal chromatography was $18 \%$ [6]. A pre-reduced and passivated sample $(0.3 \mathrm{~g})$ was pressed into a 1 in diameter wafer at $35 \mathrm{MPa}$ and the wafer was mounted in an in-situ XAS cell designed and built by Lytle [30]. The catalyst was treated in-situ in a $\mathrm{CO} / \mathrm{H}_{2} / \mathrm{N}_{2}(31 / 62 / 7 \mathrm{~mol})$ mixture or a $\mathrm{CO}_{2} / \mathrm{CO} / \mathrm{H}_{2} / \mathrm{N}_{2}$ $(10 / 10 / 70 / 10 \mathrm{~mol})$ mixture at a total pressure of $0.42 \mathrm{MPa}$. X-ray absorption spectra were measured on beamline X-10C at the NSLS facility at Brookhaven National Laboratory. Beamline resolution was approximately $2.5 \mathrm{~V}$ at the $\mathrm{Cu} \mathrm{K}$ edge $(8979 \mathrm{eV})$. Data were taken using a $0.35 \mathrm{eV}$ increment in the near-edge region and a $3.5 \mathrm{eV}$ increment through the EXAFS region. For data analysis, the edge position for $\mathrm{Cu}$ metal was defined as $8979 \mathrm{eV}$, which corresponds to the position of the first inflection point. Data were 


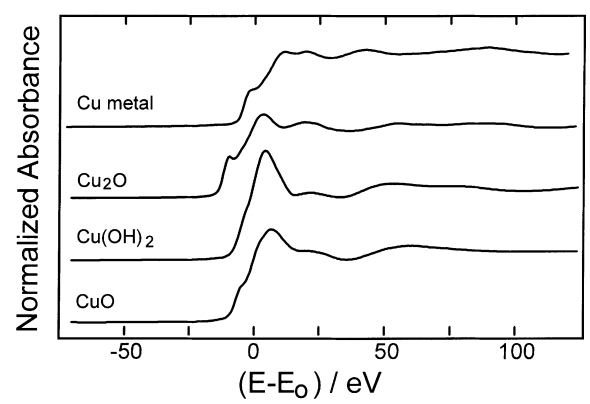

Fig. 2. X-ray absorption near-edge spectra from standard compounds used in this work. The position $\mathrm{E}_{\mathrm{o}}$ of the $\mathrm{Cu}$ K-edge is $8979 \mathrm{eV}$.

analyzed using programs EXANES, EXAPLT, and EXAFIT and procedures described previously [31].

\section{Results}

Near-edge spectra were analyzed by fitting linear combinations of spectra from $\mathrm{Cu}$ metal, $\mathrm{CuO}$, $\mathrm{Cu}(\mathrm{OH})_{2}$, and $\mathrm{Cu}_{2} \mathrm{O}$ standards from -20 to $+60 \mathrm{eV}$ energies with respect to the edge [32]. The standard spectra were allowed to shift in energy and were adjusted in amplitude, and added together to find the best fit to the sample spectra. Fractions of Cu occupying sites resembling those in the standard compounds, were given by the fraction of each standard spectrum needed to describe the near-edge spectra of actual catalysts. Near-edge spectra for standard compounds are shown in Fig. 2. In all cases, excellent fits were obtained using only $\mathrm{Cu}$ metal and $\mathrm{CuO}$ as the standards. A representative fit for an edge spectrum from the catalyst at $530 \mathrm{~K}$ in the $\mathrm{CO} / \mathrm{H}_{2}$ mixture is shown in Fig. 3. The $\mathrm{Cu}(\mathrm{OH})_{2}$ and $\mathrm{Cu}_{2} \mathrm{O}$ standard spectra were not necessary to describe any of the spectra from catalyst samples.

EXAFS was analyzed after background subtraction and Fourier transformation of the $\mathrm{k}^{1}$-weighted data in the range from 3 to $16 \AA^{-1}$. Fourier transform magnitudes from the standard compounds in Fig. 2 are shown in Fig. 4. Our analysis was restricted to the calculation of the number of $\mathrm{Cu}$ and $\mathrm{O}$ neighbors for an average $\mathrm{Cu}$ atom, although EXAFS can also be used to quantify the relative abundance of co-existing phases [33]. Back-transforms were calculated using Fourier-transformed data between 1.4

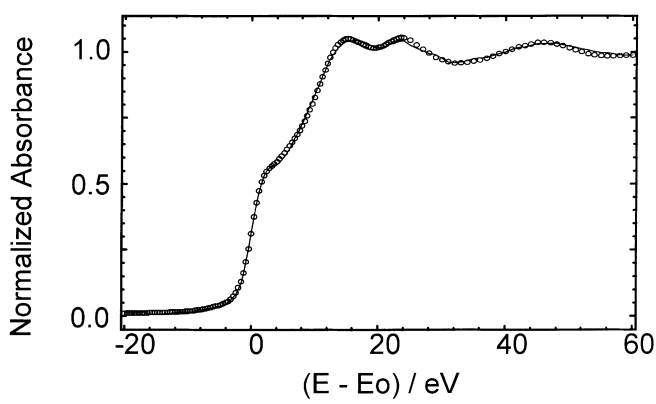

Fig. 3. Representative fit (circles) to $\mathrm{Cu} \mathrm{K}$-edge $\mathrm{X}$-ray absorption spectrum from $2.1 \mathrm{wt} . \% \mathrm{Cu} / \mathrm{SiO}_{2}$ at $510 \mathrm{~K}$ in $\mathrm{H}_{2}$. Fit was calculated between -20 and $+60 \mathrm{eV}$. The fit comprises 14 and $86 \%$ contributions from the $\mathrm{CuO}$ and $\mathrm{Cu}$ metal standard spectra, respectively.

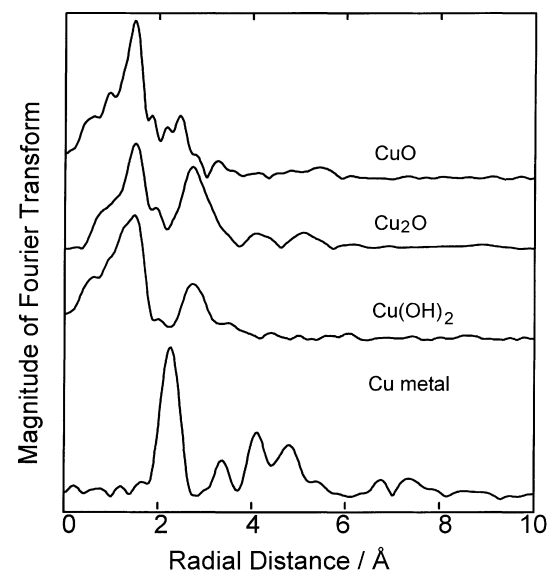

Fig. 4. Fourier transformed $\mathrm{k}^{1}$-weighted EXAFS from standard compounds, representing possible phases in methanol synthesis catalysts. All traces are on the same scale, except that the $\mathrm{Cu}$ metal trace is reduced by a factor of 3 .

and 3.4 ̊.. Back-transformed EXAFS data were fit in the range from 3 to $15 \AA^{-1}$ using oxygen and $\mathrm{Cu}$ back-scattering and phase shift functions derived from $\mathrm{CuO}$ and $\mathrm{Cu}$ metal standard spectra. A representative fit is shown in Fig. 5 for the catalyst after reduction at $530 \mathrm{~K}$. The reported $\mathrm{Cu}-\mathrm{Cu}$ coordination numbers are likely to be underestimated by $20-30 \%$. This is because the harmonic form of the Debye-Waller factor used to describe disorder is inadequate for $\mathrm{Cu}$ atoms at this temperature, in particles which present a significant fraction of atoms at their surface, since the pair-distribution function for such atoms is asymmetrical [34]. Relative values of coordination numbers, however, are correct. 


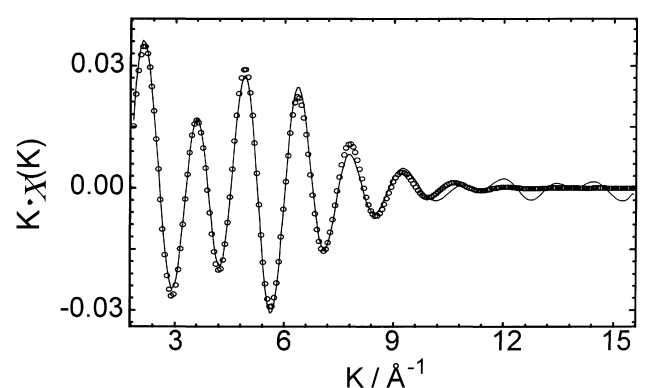

Fig. 5. Representative fit (circles) to EXAFS from the first shell of $\mathrm{Cu}$ and $\mathrm{O}$ neighbors in $2.1 \mathrm{wt} . \% \mathrm{Cu} / \mathrm{SiO}_{2}$ in $\mathrm{H}_{2}$ at $510 \mathrm{~K}$. Back-scattering and phase shift functions derived from $\mathrm{Cu}$ K-edge $\mathrm{X}$-ray absorption spectra from $\mathrm{Cu}$ foil and $\mathrm{CuO}$, measured at room temperature, were used to calculate the fit. Fit was calculated between 3 and $15 \AA^{-1}$. Fit parameters for $\mathrm{Cu}-\mathrm{Cu}$ pairs were coordination number 6.6 , interatomic distance $2.537 \AA$, and $\Delta \sigma^{2}=0.01 \AA^{2}$. Parameters for $\mathrm{Cu}-\mathrm{O}$ pairs were coordination number 0.6 , interatomic distance $1.836 \AA$, and $\Delta \sigma^{2}=0.0006 \AA^{2}$.

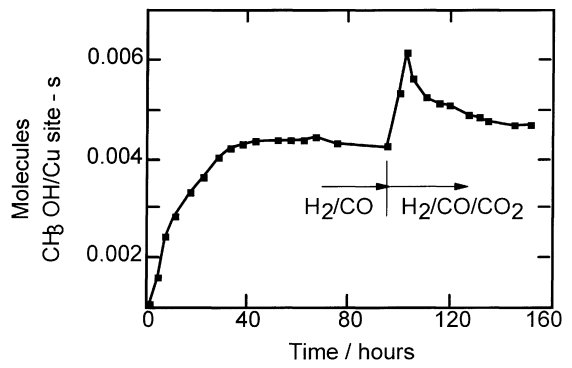

Fig. 6. Rates of production of $\mathrm{CH}_{3} \mathrm{OH}$ over $2.1 \% \mathrm{Cu} / \mathrm{SiO}_{2}$. Catalyst was pre-reduced in $4.2 \mathrm{MPa} \mathrm{H}_{2}$ at $523 \mathrm{~K}$ for $4 \mathrm{~h}$. Reaction was also at $523 \mathrm{~K}$. Gas compositions were $31 \% \mathrm{CO} / 62 \% \mathrm{H}_{2} / 7 \% \mathrm{~N}_{2}$ or $10 \% \mathrm{CO}_{2} / 10 \% \mathrm{CO} / 70 \% \mathrm{H}_{2} / 10 \% \mathrm{~N}_{2}$.

The methanol synthesis rates shown in Fig. 6 were reported previously [6]. In a $\mathrm{CO} / \mathrm{H}_{2} / \mathrm{N}_{2}(31 / 62 / 7 \mathrm{~mol})$ mixture at $4.2 \mathrm{MPa}, \mathrm{CH}_{3} \mathrm{OH}$ synthesis rates at $523 \mathrm{~K}$ increased slowly over a period of about $40 \mathrm{~h}$ before reaching steady-state values. When a mixture containing $\mathrm{CO}_{2} / \mathrm{CO} / \mathrm{H}_{2} / \mathrm{N}_{2}(10 / 10 / 70 / 10 \mathrm{~mol})$ was introduced, the rate increased sharply, and then gradually declined to a new level higher than the rate in the absence of added $\mathrm{CO}_{2}$ (Fig. 6). The apparent increase in rate upon introduction of $\mathrm{CO}_{2}$ results from hydrolysis of methoxy groups from the support surface, which is more rapid than the synthesis reactions themselves [8,35].

Figs. 7 and 8 show how the oxidation state and coordination number of $\mathrm{Cu}$ atoms responded when catalysts were contacted with synthesis gas compositions

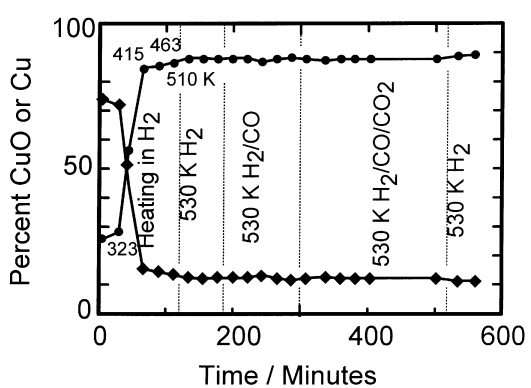

Fig. 7. Fractions of $\mathrm{Cu}$-containing phases identified by analysis of $\mathrm{Cu}$ K-near-edge spectra. $(\bullet) \mathrm{Cu}$ metal; $(\diamond)$ CuO-like phase. Conditions were $0.42 \mathrm{MPa}$, heating rate $2^{\circ} \mathrm{min}^{-1}$.

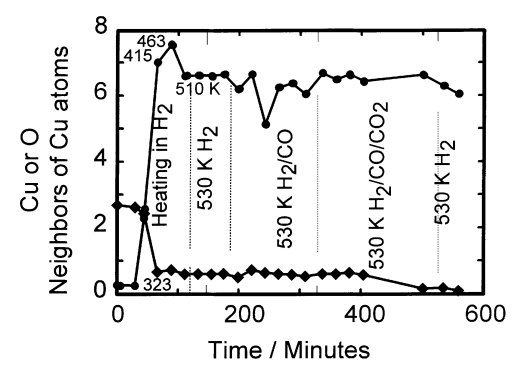

Fig. 8. Average physical environments of $\mathrm{Cu}$ atoms from analysis of $\mathrm{Cu}$ EXAFS. These results are from the same spectra that provided the edge analyses in Fig. 7. ( $)$ Cu neighbors; $(\diamond) \mathrm{O}$ neighbors.

leading to these transients. XAS data were measured in-situ, except at a total pressure of 0.4 MPa (instead of 4.2 MPa) because of XAS cell pressure limitations. Analysis of the $\mathrm{Cu} \mathrm{K}$ near-edge region shows that $\mathrm{Cu}$ reduction reached a constant value at about $473 \mathrm{~K}$, but $10 \%$ of the $\mathrm{Cu}$ atoms remain as $\mathrm{CuO}$, even at $530 \mathrm{~K}$ (Fig. 7). The $\mathrm{Cu}$ environment, characterized by the number and identity of neighboring atoms, also reached a stable state after less than $2 \mathrm{~h}$ at $473 \mathrm{~K}$ in $\mathrm{H}_{2}$ (Fig. 8). $\mathrm{Cu}$ atoms became increasingly coordinated to other $\mathrm{Cu}$ atoms during reduction, consistent with $\mathrm{Cu}$ crystallite formation, but retained some oxygen neighbors, as expected from the residual $\mathrm{CuO}$ detected by the near-edge analysis shown in Fig. 7. Since support oxygen was not detected in our previous XAS studies of metals supported on $\mathrm{SiO}_{2}$ [31], we conclude that this oxygen coordination reflects a residual $\mathrm{CuO}-$ like phase. The data in Figs. 7 and 8 show that there are no detectable chemical or morphological changes in $\mathrm{Cu}$ crystallites as the synthesis gas composition is varied in a range that causes the marked changes in methanol 
synthesis rates shown in Fig. 6. We conclude there were no changes in the environment or oxidation state of $\mathrm{Cu}$ atoms including surface atoms. Because a large fraction of the $\mathrm{Cu}$ atoms were at the surface (18\%), such changes would have been detected.

The rates of methanol synthesis presented in Fig. 6 were measured at $4.2 \mathrm{MPa}$, but the spectra summarized in Figs. 7 and 8 were measured under similar conditions except at only $0.42 \mathrm{MPa}$ due to limitations of the cell. It is reasonable to assume the slow approach to steady-state synthesis activity would be observed also at the lower pressure. Fisher and Bell used IR spectroscopy to study methanol synthesis from $\mathrm{H}_{2} / \mathrm{CO}_{2}$ (3:1) at $0.65 \mathrm{MPa}$ and $523 \mathrm{~K}$ on a $\mathrm{Cu} / \mathrm{SiO}_{2}$ catalyst [8]. They observed a $22.6 \mathrm{~h}$ transient upon switching from pure $\mathrm{H}_{2}$ to the $\mathrm{H}_{2} / \mathrm{CO}_{2}$ mixture, during which both the rate of production of $\mathrm{CH}_{3} \mathrm{OH}$ and the concentration of methoxy groups anchored to the $\mathrm{SiO}_{2}$ increased. Clausen et al. reported reconstruction of $\mathrm{Cu}$ particles in $\mathrm{Cu} / \mathrm{ZnO}$, but not $\mathrm{Cu} / \mathrm{SiO}_{2}$, upon switching from dry to wet $\mathrm{CO}_{2} / \mathrm{CO} / \mathrm{H}_{2}$ at only $0.1 \mathrm{MPa}$ pressure and $493 \mathrm{~K}$ [26].

XAS is also applicable to $\mathrm{Zn}$. Several of the reports cited herein report no detectable changes in the $\mathrm{Zn}$ component at any point in the catalyst treatments. We are not aware of any report of XAS-observable changes in the $\mathrm{Zn}$ component of $\mathrm{Cu}-\mathrm{ZnO}$ catalysts.

\section{Discussion}

The results presented here are consistent with earlier work that found $\mathrm{Cu}(0)$ to be the dominant $\mathrm{Cu}$ species under synthesis conditions, and rejected the presence of $\mathrm{Cu}(\mathrm{I})$. They also add indirect evidence for a bifunctional mechanism for methanol synthesis involving support hydroxyl groups, by eliminating an alternative explanation for the initial activation periods observed in $\mathrm{H}_{2}-\mathrm{CO}$ feeds. Incomplete reductions of $\mathrm{Cu}-\mathrm{ZnO} / \mathrm{Al}_{2} \mathrm{O}_{3}$ at $503 \mathrm{~K}[16,17]$ and of $\mathrm{Cu} / \mathrm{SiO}_{2}$ at $500 \mathrm{~K}[28,36,37]$ have been reported and the reduction of $\mathrm{CuO}_{\mathrm{x}}$ phases may lead to an increase in reaction rates with time on stream. van der Grift et al. [36,37] found by temperature programmed reduction (TPR) that several copper hydrosilicate phases reduced only above $600 \mathrm{~K}$. Brands et al. [28] found that $\mathrm{Cu}$ metal surface area increased, when a $\mathrm{Cu} / \mathrm{SiO}_{2}$ catalyst previously reduced at $600 \mathrm{~K}$ was re-reduced at $700 \mathrm{~K}$. Clausen et al. [26] reported that the morphology of $\mathrm{Cu}$ particles formed on $\mathrm{SiO}_{2}$ by reduction in various synthesis gas mixtures at $493 \mathrm{~K}$ was insensitive to gas composition. Although $\mathrm{Cu}$ particle sizes were not reported, inspection of the EXAFS data presented with the paper indicates that the $\mathrm{Cu}$ particles on $\mathrm{SiO}_{2}$ were similar in size to the particles on $\mathrm{ZnO}$, for which dynamical behavior was clearly observed.

In our study, methanol synthesis rates increased from $1 \times 10^{-3}$ to $4.5 \times 10^{3} \mathrm{CH}_{3} \mathrm{OH} / \mathrm{Cu}$ site-sec (Fig. $6)$, but neither the fraction of $\mathrm{Cu}$ that was oxidized (Fig. 7), nor the $\mathrm{Cu}$ dispersion indicated by the average $\mathrm{Cu}-\mathrm{Cu}$ coordination number (Fig. 8), changed. These structural observations are consistent with the conclusions of Clausen et al. [26] also concerning $\mathrm{Cu}$ supported on $\mathrm{SiO}_{2}$. Thus, the origin of the activity changes shown in Fig. 6 must lie in the slow accumulation of a species on the support, which participates in bifunctional methanol synthesis pathways required for $\mathrm{CO} / \mathrm{H}_{2}$ reactant mixtures. One possibility is that support surface hydroxyl groups are required for the formation of formate from $\mathrm{CO} / \mathrm{H}_{2}$ on the support, although not from $\mathrm{CO}_{2} / \mathrm{H}_{2}$ on the $\mathrm{Cu}[11,38,39]$.

Other studies have shown that, on $\mathrm{Cu} / \mathrm{ZnO}$ catalysts, $\mathrm{CO}_{2} / \mathrm{H}_{2}$ mixtures produce a formate species that is an intermediate to $\mathrm{CH}_{3} \mathrm{OH}$ on both $\mathrm{Cu}$ and $\mathrm{ZnO}$ surfaces, but that $\mathrm{CO} / \mathrm{H}_{2}$ mixtures produce formate only on the $\mathrm{ZnO}$ support surface $[8,38-43] . \mathrm{SiO}_{2}$ has few hydroxyl groups, but slow methanation side reactions (Eq. (2)) form water molecules, which can hydroxylate the surface of $\mathrm{SiO}_{2}$ and increase the surface density of required hydroxyl groups:

$\mathrm{CO}+2 \mathrm{H}_{2} \rightarrow \mathrm{CH}_{3} \mathrm{OH}$
$\mathrm{CH}_{3} \mathrm{OH}+\mathrm{H}_{2} \rightarrow \mathrm{CH}_{4}+\mathrm{H}_{2} \mathrm{O}$

The proposed bifunctional pathways become available only after hydroxyl groups are formed by hydrolysis of $\mathrm{Si}-\mathrm{O}$ bonds on the support surface. This hypothesis is supported by the observation of a transient increase in production of $\mathrm{CH}_{3} \mathrm{OH}$ upon introduction of $\mathrm{CO}_{2}$ shown in Fig. 6. Fujita et al. [35] showed that introduction of $\mathrm{CO}_{2}$ following pretreatment of $\mathrm{ZnO}$ in a $\mathrm{CO} / \mathrm{H}_{2}$ mixture yielded a similar transient that was due to hydrolysis of methoxy groups from the $\mathrm{ZnO}$ surface. The slow approach to steady-state methanol synthesis rates was also observed on $\mathrm{Cu}-\mathrm{ZnO}$ catalysts. For example, 
Lee et al. [42] reported that steady-state rates were reached on $\mathrm{Cu} / \mathrm{ZnO} / \mathrm{Al}_{2} \mathrm{O}_{3}$ after 5 and $20 \mathrm{~h}$ on stream for $\mathrm{CO}_{2} / \mathrm{H}_{2}$ and $\mathrm{CO} / \mathrm{H}_{2}$ feeds, respectively. These transients were attributed to the spillover of reactive intermediates or hydrogen atoms from $\mathrm{Cu}$ to $\mathrm{ZnO}$. Such spillover and a bifunctional synthesis mechanism were demonstrated by infrared spectroscopy to occur during methanol synthesis from $\mathrm{CO}_{2}$-containing reactants $[8,38]$. There is also evidence that reconstruction of $\mathrm{Cu}$ particles supported on $\mathrm{ZnO}$ [26-29] contributes to these transients, but we detected no structural changes during our transients. It is possible that the unreduced $\mathrm{Cu}$ species in our $\mathrm{Cu} / \mathrm{SiO}_{2}$ catalysts can adsorb reactive species in the same manner as the $\mathrm{ZnO}$ surface. More generally, residual $\mathrm{Cu}$ oxide species acting as a promoter in the same capacity as $\mathrm{ZnO}$, may reconcile our successful $\mathrm{CH}_{3} \mathrm{OH}$ synthesis over $\mathrm{Cu} / \mathrm{SiO}_{2}$ from $\mathrm{CO} / \mathrm{H}_{2}$, with other studies which show that $\mathrm{Cu} / \mathrm{SiO}_{2}$ does not catalyze $\mathrm{CH}_{3} \mathrm{OH}$ synthesis from $\mathrm{CO} / \mathrm{H}_{2}$ mixtures [10].

Although we detect $\mathrm{Cu}$ (II) in our $\mathrm{Cu} / \mathrm{SiO}_{2}$ catalyst, the fraction of the $\mathrm{Cu}$ atoms in this form does not correlate with the rate of methanol synthesis. Other groups have already concluded that $\mathrm{Cu}$ metal is the only required form of $\mathrm{Cu}$ at least for $\mathrm{CO}_{2}$-containing synthesis gas reactants [11,12], and have explicitly rejected the presence of $\mathrm{Cu}(\mathrm{I})$ in working catalysts. Chemical evidence from Han et al. [44,45] eliminates at least one possible role of oxidized $\mathrm{Cu}$ as an acceptor site for a formate intermediate in methanol synthesis. They showed that copper formate, or copper formate mixed with $\mathrm{Al}_{2} \mathrm{O}_{3}$ yielded formic acid as the exclusive product upon heating in either $\mathrm{He}$ or $\mathrm{H}_{2}$. In contrast, zinc formate and mixtures of copper formate with $\mathrm{ZnO}$ yielded substantial methanol and methyl formate when heated in $\mathrm{H}_{2}$.

\section{Conclusions}

As currently practiced, methanol synthesis employs a catalyst prepared from $\mathrm{Cu}, \mathrm{Zn}$, and $\mathrm{Al}$ or $\mathrm{Cr}$ oxides. $\mathrm{ZnO}$ and $\mathrm{Cu}$, with or without other oxides, are also effective catalysts. The feed may contain $\mathrm{CO}_{2}, \mathrm{CO}$, and $\mathrm{H}_{2}$. The same catalysts are used for water-gas shift reactions, so $\mathrm{H}_{2} \mathrm{O}$ is likely to be present in the reactor. This system has been the subject of many in-situ and ex-situ studies using X-ray absorption spectroscopy
(XAS). This body of work provides a useful test of the XAS technique, since it is relatively new and the data analysis is still evolving. The consistency among different groups is reassuring.

Most groups that have brought XAS to bear agree that copper is mostly or entirely reduced in the working catalyst. Residual $\mathrm{Cu}$ oxide is present following low temperature reduction treatments sometimes employed. Substantial mixed oxides of $\mathrm{Cu}$ with $\mathrm{Zn}$ were detected in some cases in which the catalyst was prepared in a reactor and then transferred to a spectroscopic cell, under conditions intended to avoid exposure to air. Autoxidation of $\mathrm{Cu}(0)$ by protons was reported when $\mathrm{Cu} / \mathrm{ZnO}$ catalysts were reduced at low temperature and then removed from the reducing environment. Reconstruction of $\mathrm{Cu}$ particles in $\mathrm{Cu} / \mathrm{ZnO}$ catalysts, in response to $\mathrm{H}_{2} \mathrm{O}$ in the feed, was also observed.

Our own XAS study of a $\mathrm{Cu} / \mathrm{SiO}_{2}$ catalyst showed no changes in the $\mathrm{Cu}$ metal function during the initial gradual increase in methanol synthesis activity after contact with a $\mathrm{CO} / \mathrm{H}_{2}$ mixture. We suggest that methanol synthesis from $\mathrm{CO} / \mathrm{H}_{2}$, but not from $\mathrm{CO}_{2} / \mathrm{H}_{2}$, requires a bifunctional mechanism involving support hydroxyl groups. The induction of activity for synthesis from $\mathrm{CO} / \mathrm{H}_{2}$ reflects hydroxyl formation from hydrolysis of $\mathrm{Si}-\mathrm{O}$ bonds, which is slow because water is only available from very slow methanation side reactions.

\section{Acknowledgements}

Research carried out in part at the National Synchrotron Light Source, Brookhaven National Laboratory, which is supported by the US Department of Energy, Division of Materials Sciences and Division of Chemical Sciences (DOE contract number DE-AC02-76CH000 16).

\section{References}

[1] G. Natta, in: P.H. Emmett (Ed.), Catalysis, vol. III, p. 349.

[2] G.C. Chinchen, K.C. Waugh, J. Catal. 97 (1986) 280.

[3] H. Baussart, R. Delobel, M. Le Bras, D. Le Maguer, J. Leroy, Appl. Catal. 14 (1985) 381.

[4] L.-S. Kau, K.O. Hodgson, E.I. Solomon, J. Am. Chem. Soc. 111 (1989) 7103. 
[5] J. Lin, P. Jones, J. Guckert, E.I. Solomon, J. Am. Chem. Soc. 113 (1991) 8312

[6] J.L. Robbins, E. Iglesia, C.P. Kelkar, B. DeRites, Catal. Lett. 10 (1991) 1.

[7] H. Idriss, J.P. Hindermann, R. Kieffer, A. Kiennemann, A. Vallet, C. Chauvin, J.C. Lavalley, P. Chaumette, J. Mol. Catal. 42 (1987) 205.

[8] I.A. Fisher, A.T. Bell, J. Catal. 172 (1997) 222.

[9] M. Muhler, E. Tornqvist, L.P. Nielsen, B.S. Clausen, H. Topsoe, Catal. Lett. 25 (1994) 1.

[10] L.E.Y. Noneman, V. Ponec, Catal. Lett. 7 (1990) 213.

[11] P.B. Rasmussen, P.M. Holmblad, T. Askgaard, C.V. Ovesen, P. Stoltze, J.K. Norskov, I. Chorkendorff, Catal. Lett. 26 (1994) 373.

[12] J. Yoshihara, S.C. Parker, A. Schafer, C.T. Campbell, Catal. Lett. 31 (1995) 513.

[13] P. Porta, M.C. Campa, G. Fierro, M. Lo Jacono, G. Minelli, G. Moretti, L. Stoppa, J. Mater. Chem. 3 (1993) 505.

[14] J.C. Frost, Nature 334 (1988) 577.

[15] F.W. Lytle, D.E. Sayers, E.B. Moore Jr., Appl. Phys. Lett. 24 (1974) 45.

[16] G. Vlaic, J.C.J. Bart, W. Cavigiolo, S. Mobilio, Chem. Phys. Lett. 76 (1980) 453.

[17] G. Vlaic, J.C.J. Bart, W. Cavigiolo, B. Pianzola, S. Mobilio, J. Catal. 96 (1985) 314.

[18] G. Sankar, S. Vasudevan, C.N.R. Rao, J. Chem. Phys. 85 (1986) 2291.

[19] G. Sankar, S. Vasudevan, C.N.R. Rao, Chem. Phys. Lett. 127 (1986) 620.

[20] T. Arunarkavalli, G.U. Kulkarni, C.N.R. Rao, Catal. Lett. 20 (1993) 259.

[21] B.S. Clausen, B. Lengeler, B.S. Rasmussen, W. Niemann, H. Topsoe, J. de Physique 47 (1986) C8-C237.

[22] B.S. Clausen, H. Topsoe, Catal. Today 9 (1991) 189.

[23] J.W. Couves, J.M. Thomas, D. Waller, R.H. Jones, A.J. Dent, G.E. Derbyshire, G.N. Greaves, Nature 354 (1991) 465.

[24] B.S. Clausen, G. Steffensen, B. Fabius, J. Villadsen, R. Feidenhans'l, H. Topsoe, J. Catal. 132 (1991) 524.

[25] B.S. Clausen, L. Graback, G. Steffensen, P.L. Hansen, H. Topsoe, Catal. Lett. 20 (1993) 23.
[26] B.S. Clausen, J. Schiotz, L. Grabaek, C.V. Ovesen, K.W Jacobsen, J.K. Norskov, H. Topsoe, Topics Catal. 1 (1994) 367.

[27] C.V. Ovesen, B.S. Clausen, J. Schiotz, P. Stoltze, H. Topsoe, J.K. Norskov, J. Catal. 168 (1997) 133.

[28] D.S. Brands, E.K. Poels, T.A. Krieger, O.V. Makarova, C. Weber, S. Veer, A. Bliek, Catal. Lett. 36 (1996) 175.

[29] K. Tohji, Y. Udagawa, T. Mizushima, A. Ueno, J. Phys. Chem. 89 (1985) 5671.

[30] F.W. Lytle, P.S.P. Wei, R.B. Greegor, G.H. Via, J.H. Sinfelt, J. Chem. Phys. 70 (1979) 4849.

[31] G.H. Via, K.F. Drake Jr., G. Meitzner, F.W. Lytle, J.H. Sinfelt, Catal. Lett. 5 (1990) 25.

[32] G. Meitzner, E.S. Huang, Fresenius J. Anal. Chem. 342 (1992) 61.

[33] T.L. Neils, J.M. Burlitch, Analytica Chim. Acta 233 (1990) 229.

[34] B.S. Clausen, L. Grabaek, H. Topsoe, L.B. Hansen, P. Stoltze, J.K. Norskov, O.H. Nielsen, J. Catal. 141 (1993) 368.

[35] S. Fujita, H. Ito, N. Takezawa, Bull. Chem. Soc. Jpn. 66 (1993) 3094.

[36] C.J.G. van der Grift, A. Mulder, J.W. Geus, Appl. Catal. 60 (1990) 181.

[37] C.J.G. van der Grift, P.A. Elberse, A. Mulder, J.W. Geus, Appl. Catal. 59 (1990) 275

[38] S. Fujita, M. Usui, H. Ito, N. Takezawa, J. Catal. 157 (1995) 403.

[39] J. Saussey, J.C. LaValley, J. Mol. Catal. 50 (1989) 343.

[40] J.-C. Lavalley, J. Saussey, J. Lamotte, T. Rais, J. Mol. Catal. 17 (1982) 289.

[41] J. Saussey, J.-C. Lavalley, J. Lamotte, T. Rais, J. Chem. Soc Chem. Commun. (1982) 278.

[42] J.S. Lee, K.H. Lee, S.Y. Lee, Y.G. Kim, J. Catal. 144 (1993) 414.

[43] J. Saussey, J.-C. Lavalley, C. Bovet, J. Chem. Soc. Faraday Trans. 1(78) (1982) 1457.

[44] O.-S. Joo, K.-D. Jung, S.-H. Han, S.-J. Uhm, J. Catal. 157 (1995) 259.

[45] O.-S. Joo, K.-D. Jung, S.-H. Han, S.-J. Uhm, D.-K. Lee, S.-K. Ihm, Appl. Catal. A: General 135 (1996) 273. 